\title{
排尿機能障害に括ける春髄誘発電位測定の意義
}

一硬膜外導出法に関する基礎的検討一

\begin{tabular}{|c|c|c|c|}
\hline \multirow[b]{2}{*}{ 福島県立医科大学泌尿器科教室 } & 山 & \multicolumn{2}{|c|}{ 口 } \\
\hline & 深 & 谷 & 保 \\
\hline & 白 & 岩 & 康 \\
\hline 太田綜合病院附属熱海総合病院麻酔科 & 石 & 崎 & 恵 \\
\hline 整形外科 & 丸 & 山 & 俊 \\
\hline
\end{tabular}

\section{EVOKED ELECTROSPINOGRAM OF BULVOCAVERNOSUS REFLEX RECORDED FROM EPIDURALSPACE}

\author{
Osamu Yamaguchi, Yasuo Fukaya and Yasuo Shiraiwa \\ Department of Urology, Fukushima Medical College, Fukushima \\ Keiji Ishizaki and Toshiaki Maruyama
}

Departmentof Anesthesiology and Orthopedics, Atami general Hospital, Koriyama

The human evoked electrospinogram (EESG) of bulbocavernosus reflex was examined by an epidural recording method. When the recording electrode was located at the level of the sacral spinal cord in the epidural space, the potentials elicited by penile electrostimulation could be recorded from 10 subjects with suprasacral lesions. This electrospinogram is a response in the corresponding spinal segment and termed as a segmental EESG. In addition, the urodynamic study was done in 6 of these 10 subjects with detrusor hyperreflexia with DSD.

The segmental EESG consisted of the initial positive spike $\left(\mathrm{P}_{1}\right)$ and a subsequent slow and sharp negative wave $\left(\mathrm{N}_{1}\right)$, followed by a slower positive wave $\left(\mathrm{P}_{2}\right)$. The $\mathrm{P}_{1}$-wave had a peripheral latency of 9.8 $\mathrm{msec}$ and a duration of $1.20 \mathrm{msec}$. The $\mathrm{N}_{1}$-wave had a peripheral latency of $13.4 \mathrm{msec}$, a central latency of $3.6 \mathrm{msec}$ and a duration of $6.1 \mathrm{msec}$. The $\mathrm{P}_{2}$-wave had a peripheral latency of $25.8 \mathrm{msec}$, a central latency of $15.8 \mathrm{msec}$ and a duration of $28.0 \mathrm{msec}$.

The $\mathrm{P}_{1}$-wave easily noticed at the stimulation strength of $20 \mathrm{~V}$ and had the lowest threshold among these components. As the stimulation strength was increased, the amplitude of the $\mathrm{P}_{2}$-wave grew quickly to reach a maximum while the increase in amplitude of the $\mathrm{N}_{1}$-wave had a wider range.

These characteristics were very similar to those of EESG elicited by stimulation of the peripheral nerve at an extremity. Thus, in the segmental EEGS of bulbocacernosus reflex, the origin of each component $\left(\mathrm{P}_{1}, \mathrm{~N}_{1}\right.$, and $\left.\mathrm{P}_{2}\right)$ seems to have the same basis as that established in the evoked spinal somatosensory potentials, showing that the $\mathrm{P}_{1}$-wave is related to the arrival of afferent volleys at the dorsal root and the subsequent $\mathrm{N}_{1}$ and $\mathrm{P}_{2}$-waves reflect the activity of interneurons and primary afferent depolarization, respectively.

In 2 patients with sacral lesions or peripheral neuropathy, the urodynamic evaluation showed that both patients had the detrusor areflexia. Regarding the EESG of these 2 subjects, any potentials could not be recorded from 1 patient with sacral lesion. However, in the remaining one with peripheral neuropathy, only the $\mathrm{P}_{1}$-wave was recorded.

It seems from these results that the epidural recording of EESG is an important means in neurourology because it provides with much infromation on the spinal cord function.

要旨：硬膜外導出法によって, 球海綿体反射によるヒト脊髄誘発電位を検討した。仙䯣以下が保存され ている頝胸䯣損傷患者 10 名からは, 導出電極を硬膜外腔で仙髄分節の高さに置くと, 再現性のある分節 
性脊髄誘発電位を得ることができた。また，これら10名の患者のうち 6 名に urodynamic studyを施行 したところ，6名とも DSDを伴なら detrusor hyperreflexia を示した。

分節性脊髄誘発電位は特徵的な波形を有し, 最初の陽性波 $\left(\mathrm{P}_{1}\right.$ 波), 次の陰性波 $\left(\mathrm{N}_{1}\right.$ 波) および最後の 陽性波（ $\mathrm{P}_{2}$ 波）から構成されていた。 $\mathrm{P}_{1}$ 波は末梢潜時 $9.8 \mathrm{msec}$, 持続時間 $1.20 \mathrm{msec}$ を示し，小さなスパ イク状電位であった. $\mathrm{N}_{1}$ 波は末梢潜時 $13.4 \mathrm{msec}$, 中枢潜時 $3.6 \mathrm{msec}$, 持続時間 $6.1 \mathrm{msec}$ を有するシャープ な陰性波であった。 $\mathrm{P}_{2}$ 波は末梢潜時 $25.8 \mathrm{msec}$, 中枢潜時 $15.8 \mathrm{msec} て ゙$ 出現する大きな陽性電位で, 持続時 間が $28.0 \mathrm{msec}$ ともっとも長く, 緩徐な変動を示した.

これら成分波の陰茎電気刺激強度に対する反応はおたがいに異なり， $\mathrm{P}_{1}$ 波は閾值がもっとも低く，20 $\mathrm{V}$ の弱刺激でも容易に記録された。一方， $\mathrm{N}_{1}$ 波は刺激強度増加に対しその振幅がほぼ直線的に増大した が， $\mathrm{P}_{2}$ 波は刺激電圧 $60 \mathrm{~V}$ 付近から飽和しそれ以上増加しなかった。

各成分波に関する以上の性質は, 四肢の末梢神経刺激時に得られる脊䯣誘発電位の性質と同じであり, この場合に確立されている成分波の起源(すなわち, $\mathrm{P}_{1}$ 波が後根に流入する活動電位, $\mathrm{N}_{1}$ 波が介在ニュー ロンの興奮， $\mathrm{P}_{2}$ 波が 1 次求心性線維の脱分極をそれぞれ反映するといら考方方）を，今回我々が検討し た球海綿体反射の脊髄誘発電位にもそのまま適応できるものと扣もわれる.

一方, 仙䯣以下に障害のある患者 2 名はいずれも detrusor areflexia を示したが，このうち仙髄自体が 損傷された症例では脊䯣誘発電位を記録することができなかった．残りの 1 例は直腸癌の術後に発生し た末梢神経障害で，成分波のらち $\mathrm{P}_{1}$ 波だけが遅れた潜時で記録された。

以上より，硬膜外導出法による春䯣誘発電位の記録は，春髄からの情報量が多く，従来と異なった視 点から下部尿路機能を検討することが可能となり, 今後, 神経泌尿器科領域で重要な位置を占めるもの と打もわれる。

\section{緒 言}

近年, 泌尿器科領域でも神経因性膀胱やインポテン ス患者を対象に，末梢神経刺激時の反応を脳波 ${ }^{1}$ や筋

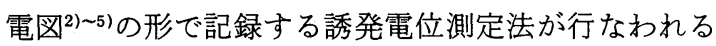
ようになった。一方, 球海綿体反射に代表されるよう に神経泌尿器科的に重要な反射は脊髄に中枢をもつも のが多く，もし脊䯣から誘発電位が安定した形で記録 できれば臨床応用の上で利用価値が大きいものと考支 られている。しかし脊䯣誘発電位の研究は少なく, わ ずかに体表面導出による報告6)があるだけにすぎな い.

一般に脊髄誘発電位測定法は, その解剖学的問題の ため実用化が遅れていた。最近になり下地らが開発し た硬膜外導出法が778)，やっと安定した波形の記録を可 能にし, 現在この方法は神経内科 ${ }^{910)}$ や脊髄外科 ${ }^{11) ~ 13) ~}$ の臨床に利用されている. さらに, 硬膜外導出法によ る誘発電位は体表面から得られるすのとは本質的に異 なり，春髄内ニューロンの特徵的活動を反映すると言 われている14).

我々は硬膜外導出法のもつ以上の利点に注目し，本

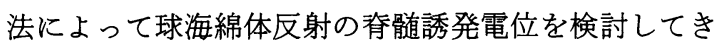
た.この研究では泌尿器科領域応用への第一歩として, その記録方法や誘発波形の再現性および性質などにつ
き基礎的検討を加えるとともに，本法の臨床的意義に ついて若干の考察を行なった。

\section{対象および方法}

対象は23歳から64歳（平均40.4歳）の男子患者12名 で, 仙髄より上方に障害をもつ春髄損傷患者 10 名, 仙 髄および末梢神経障害患者 2 名である(表 2 ). 全例と も排尿機能障害を訴兄ていたが，このうち8例につい て膀脱内圧, 直腸内圧, 排尿筋圧および尿道外括約筋 筋電図からなる urodynamic studyを施行し診断し た.

脊髄誘発電位の導出電極には, 硬膜外麻酔用チュー ブの先端に 2 個の電極を取りつけたものを使用した。 この導出電極を硬膜外ブロックの手技にしたがって硬 膜外腔へ㨂入し，目的とする高さに電極を置いた。誘

表 1 分節性脊䯣誘発電位の性質

\begin{tabular}{l|c|r|r}
\hline 誘発脊髄電位 & $\mathrm{P}_{1}$ & \multicolumn{1}{c|}{$\mathrm{N}_{1}$} & \multicolumn{1}{c}{$\mathrm{P}_{2}$} \\
\hline 末梢潜時 $(\mathrm{msec})$ & $9.0 \pm 0.4$ & $13.4 \pm 0.5$ & $25.8 \pm 3.1$ \\
中枢潜時 $(\mathrm{msec})$ & 0 & $3.6 \pm 0.5$ & $15.8 \pm 3.1$ \\
持続時間 $(\mathrm{msec})$ & $1.20 \pm 0.5$ & $6.1 \pm 1.1$ & $28.0 \pm 3.2$ \\
振幅 $(\mu \mathrm{V})$ & $0.1-0.5$ & $1.2-5.0$ & $2.5-9.0$ \\
\hline 誘発筋電図 & & & \\
末梢潜時 $(\mathrm{msec})$ & $38.1 \pm 4.53$ & & \\
\hline
\end{tabular}


表 2 対象患者の障害部位, urodynamic study および誘発電位

\begin{tabular}{|c|c|c|c|c|}
\hline No. & 年齢 & 障害部位 & urodynamic study 所見 & 脊骾誘発電位 \\
\hline 1 & 45 & 頸䯣 $\left(\mathrm{C}_{6-8}\right)$ & $-\quad$ & $\mathrm{P}_{1} \mathrm{~N}_{1} \mathrm{P}_{2}$ \\
\hline 2 & 64 & 頸䯣 $\left(\mathrm{C}_{5-6}\right)$ & $\begin{array}{l}\text { detrusor hyperreflexia } \\
\text { DSD }(+)\end{array}$ & $\mathrm{P}_{1} \mathrm{~N}_{1} \mathrm{P}_{2}$ \\
\hline 3 & 53 & 胸髄 $\left(T_{5}\right)$ & $\longrightarrow$ & $\mathrm{P}_{1} \mathrm{~N}_{1} \mathrm{P}_{2}$ \\
\hline 4 & 23 & 頸髄 $\left(\mathrm{C}_{5-6}\right)$ & $\begin{array}{l}\text { detrusor hyperreflexia } \\
\text { DSD }(+)\end{array}$ & $\mathrm{P}_{1} \mathrm{~N}_{1} \mathrm{P}_{2}$ \\
\hline 5 & 34 & 頸髄 $\left(\mathrm{C}_{4}\right)$ & $\begin{array}{l}\text { detrusor hyperreflexia } \\
\text { DSD }(+)\end{array}$ & $\mathrm{P}_{1} \mathrm{~N}_{1} \mathrm{P}_{2}$ \\
\hline 6 & 38 & 頸髄 $\left(\mathrm{C}_{5}\right)$ & & $\mathrm{P}_{1} \mathrm{~N}_{1} \mathrm{P}_{2}$ \\
\hline 7 & 34 & 胸髄 $\left(\mathrm{T}_{3-4}\right)$ & $\begin{array}{l}\text { detrusor hyperreflexia } \\
\text { DSD }(+)\end{array}$ & $\mathrm{P}_{1} \mathrm{~N}_{1} \mathrm{P}_{2}$ \\
\hline 8 & 24 & 頸髄 $\left(\mathrm{C}_{4-6}\right)$ & & $\mathrm{P}_{1} \mathrm{~N}_{1} \mathrm{P}_{2}$ \\
\hline 9 & 26 & 胸髄 $\left(T_{1}\right)$ & $\begin{array}{l}\text { detrusor hyperreflexia } \\
\text { DSD }(+)\end{array}$ & $\mathrm{P}_{1} \mathrm{~N}_{1} \mathrm{P}_{2}$ \\
\hline 10 & 62 & 頸髄 $\left(\mathrm{C}_{5}\right)$ & $\begin{array}{l}\text { detrusor hyperreflexia } \\
\text { DSD }(+)\end{array}$ & $\mathrm{P}_{1} \mathrm{~N}_{1} \mathrm{P}_{2}$ \\
\hline 11 & 26 & 仙髄 $\left(\mathrm{S}_{2-3}\right)$ & $\begin{array}{l}\text { detrusor areflexia } \\
\text { denervated ext. sphincter }\end{array}$ & 記録不能 \\
\hline 12 & 56 & 末梢神経 & $\begin{array}{l}\text { detrusor areflexia } \\
\text { nonrelaxing ext. sphincter }\end{array}$ & $\mathrm{P}_{1}$ 波のみ \\
\hline
\end{tabular}

$\mathrm{P}_{1}, \mathrm{~N}_{1}, \mathrm{P}_{2}$ は分節性脊䯣誘発電位の成分波を示す。

発電位の波形解析ができるように，ここで使用した双 極電極のらち上方の極を接地して不関電極とし，下方 の極から単極誘導による記録を行なった。な打電極の 位置確認は最初の 2 例に対しX線単純写真で行なった が，後にX線テレビ透視下で導出電極を挿入する方法 を用いた。

実際に誘発電位の記録は，次のようにして行なった （図 1 ）. 被験者の陰茎周囲を巻きつけた 2 本のベルト 型電極に, 持続時間 $0.2 \mathrm{msec}$, 電圧 $10 \sim 80 \mathrm{~V}$ の矩形波刺 激を毎秒 1 ないし 2 回の割合で加えて球海綿体反射を 起こした。同時に硬膜外腔から脊髄誘発電位を，肛門 括約筋に刺入した同芯針電極より誘発筋電図をそれぞ

図 1 硬膜外導出法による脊䯣誘発電位の記録方法

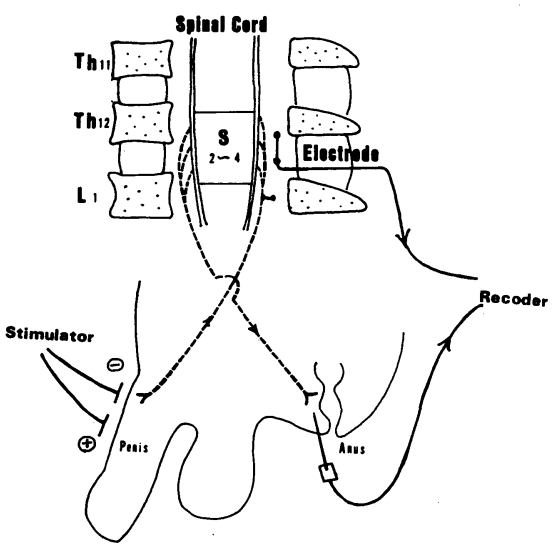

れ導出し, Neuropac-II (日本光電社製) で加算平均処 理を加光誘発電位波形として記録した。な抗この記録 計では，基線より上方を陽性電位，下方を陰性電位と なるように設定してある。また，フィルターの条件は， high cut $1 \mathrm{KHz}$, low cut $20 \mathrm{~Hz}$ とした。

球海綿体反射の脊䯣中权は仙髄にあるので，仙髄以 下が保存されている患者 10 名を対象に春髄誘発電位に 関する基本的事項を種々の角度から検討し，波形の特 性を決定した。次に仙䯣以下に障害のある患者 2 名に ついても誘発電位測定を試み，全症例を合せて神経障 害部位や urodynamic study の結果と比較した。

\section{結 果}

\section{1）脊髄誘発電位々電極の位置}

硬膜外腔に挿入した導出電極は，X線単純写真でも テレビ透視下でも容易に確認することができた（図 2 ). そこで刺激電圧を $60 \mathrm{~V}$ ，加算回数を 128 回に固定 し, 電極の位置を第 6 胸椎から第 2 腰椎までの範囲で 変化させ，各位置における誘発電位を検討した。

導出電極を第 12 胸椎から第 1 腰椎に至る区間に置く と,もっとも安定した特徵的な誘発電位を得ることが できた。この誘発電位は，電極の置かれた区間が球海 綿体反射中枢のある仙䯣分節に相当するので，分節性 脊䯣誘発電位であることが判明した，図 3 に示すよう に，球海綿体反射によって誘発された分節性春䯣電位 の波形は，最初に出現する小さなスパイク電位（以下 $\mathrm{P}_{1}$ 波と略）とこれに続く陰性波（以下 $\mathrm{N}_{1}$ 波と略）およ 
図 2 X線写真による導出電極の位置. 个印は電極の 位置を示す。

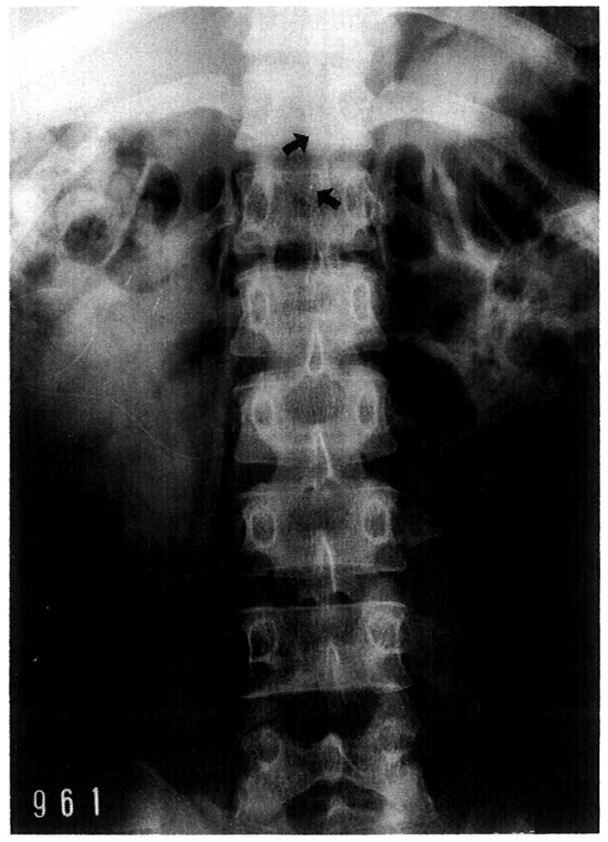

因 3 球海綿体反射による脊骵誘発電位。分節性誘発 電位の基本波形を示す. 刺激電圧 $60 \mathrm{~V}$, 加算回数 128 回, SCEP (Spinal cord evoked potential)

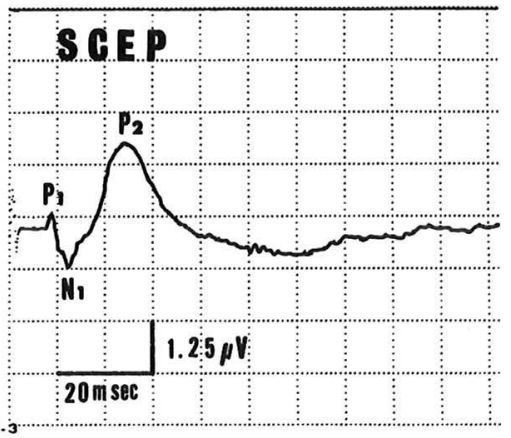

び緩徐な陽性電位（以下 $\mathrm{P}_{2}$ 波と略）から成り立ってい た。この基本波形の再現性はきわめて高く, 電極が硬 膜外腔で仙髄の高さに置かれているかぎり, 記録を数 回試みても各波形はよく一致した（図 4A）.

一方，電極を仙髄分節より上方に，椎体レベルでは 第11胸椎より上方に置くと，波形の再現性が失なわれ てしまい，誘発電位と判定するには困難であった（図 4 B). 反対に電極の位置を第 2 腰椎より下方で馬尾神 経の近くへ移動すると, 誘発電位はスパイク状の陽性
図 4 導出電極の位置と脊䯣誘発電位.A以電極を第 12胸椎の高さに置いたとさの記録を示す，4回記録 しても再現性の高い誘発電位が得られる。B電極 を第 6 胸椎の高さに，Cは第 2 腰椎の高さにそれぞ れ置いたときの記録を示す。

A

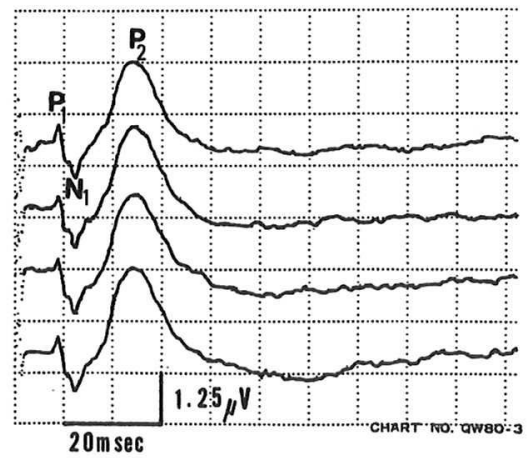

B
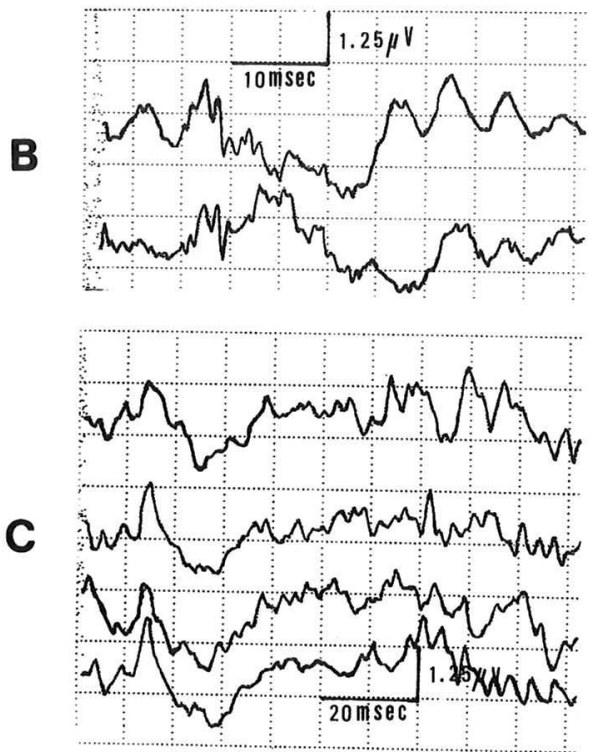

波や不安定な陰性波となって記録され，分節性誘発電 位の基本波形とは大きく異なっていた（図 4C）。

2）分節性脊髄誘発電位の性質

前述したように分節性春䯣誘発電位の再現性は高 く,誘発電位記録計の加算回数を64から256回まで变党 てみたが，ぞの回数でも明瞭な波形を記録できた。そ こで次の検討では加算回数を128回と一定にし,陰茥電 気刺激の強度と各成分波の示す反応との関係を調べ た。

$\mathrm{P}_{1}$ 波は 3 個の成分波のらち閾值がもっとも低く（図 5 ), 20V. ではかならず誘発され，時には $20 \mathrm{~V}$ 以下の弱 刺激でも記録されることがわかった。な和 $\mathrm{P}_{1}$ 波の振幅 
図 5 分節性誘発電位の刺激強度に対する反応. 加算 回数はどれも 128 回. $\mathrm{P}_{1}$ 波は $20 \mathrm{~V}$ で出現している.

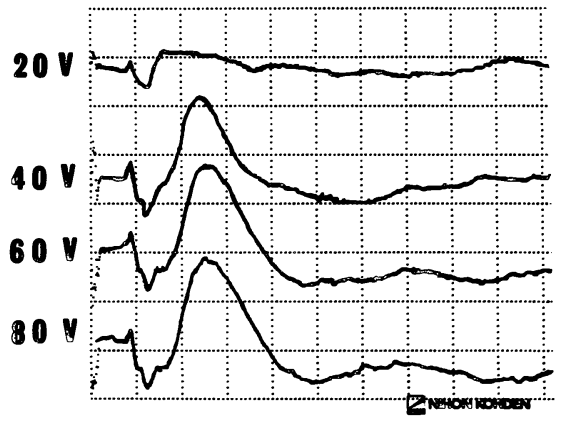

は, 刺激電圧を増加させてもほとんど変化しなかった。 したがって図 5 に示すように, 最初の弱い刺激ではま ず $\mathrm{P}_{1}$ 波が出現し，刺激強度を上げていくと後続する $\mathrm{N}_{1}$ 波と $\mathrm{P}_{2}$ 波が増大し，次第に完全な波形となって記 録された。さらに $\mathrm{N}_{1}$ 波と $\mathrm{P}_{2}$ 波とでは, 刺激強度に対す る反応様式が明らかに異なっていた。すなわち， $\mathrm{N}_{1}$ 波 は刺激強度の増加に応じて，その電位もほぼ直線的に 増大した（図 6A)。これに対し $\mathrm{P}_{2}$ 波は急速に増大し， 刺激電圧 $60 \mathrm{~V}$ でその反応がほぼ飽和状態となり，80V まで刺激を強めてもそれ以上の増加を示さなかった (図 6B)。

次に刺激電圧を $60 \mathrm{~V}$, 加算回数を 128 回に固定して, 末梢潜時，中枢潜時，持続時間および電位振幅などを 検討した。な拉，末梢潜時は陰茥刺激から各成分波が 出現するまでの時間とし，脊髄に入ってからの時間経 過を表わす中枢潜時は $\mathrm{P}_{1}$ 波から各成分波までの長さ とした。 $\mathrm{P}_{1}$ 波は陰茥刺激から約 $9.8 \mathrm{msec}$ の潜時で最初 に出現する電位で，持続時間が $1.2 \mathrm{msec}$ と短かく振幅 も $0.5 \mu \mathrm{V}$ 以下であり，小さなスパイク状電位としての 特徴を示した。次いで $\mathrm{P}_{1}$ 波から $3.6 \mathrm{msec}$ (中枢潜時) の後に現われる $\mathrm{N}_{1}$ 波は，持続時間が $6.1 \mathrm{msec}$ と比較 的短かくシャープな波形をもつ陰性電位であった。最 後に出現する $\mathrm{P}_{2}$ 波は，振幅が 2.5 から $9.0 \mu \mathrm{V}$ まであ り，持続時間も $28 \mathrm{msec}$ ともっとも長いことから，緩徐 に大さく変動する陽性電位であった。表 1 には，これ らの測定結果を示した。

3）誘発筋電図との同時記録

図 7 は，脊髄誘発電位と誘発筋電図との同時記録例 を表わす。この記録から，陰茎刺激が陰部神経の知覚 線維を通り脊髄後根に到達する時間は， $\mathrm{P}_{1}$ 波の末梢潜 時として捉えることができる，次いで起こる脊髄内 ニューロンの活動は $\mathrm{N}_{1}$ 波と $\mathrm{P}_{2}$ 波に反映され，最後に
図 $6 \mathrm{~N}_{1}$ 波 (A) および $\mathrm{P}_{2}$ 波 (B) の刺激強度に対京

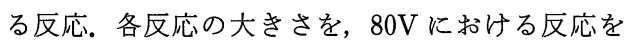
100\%として縦軸に表わした。
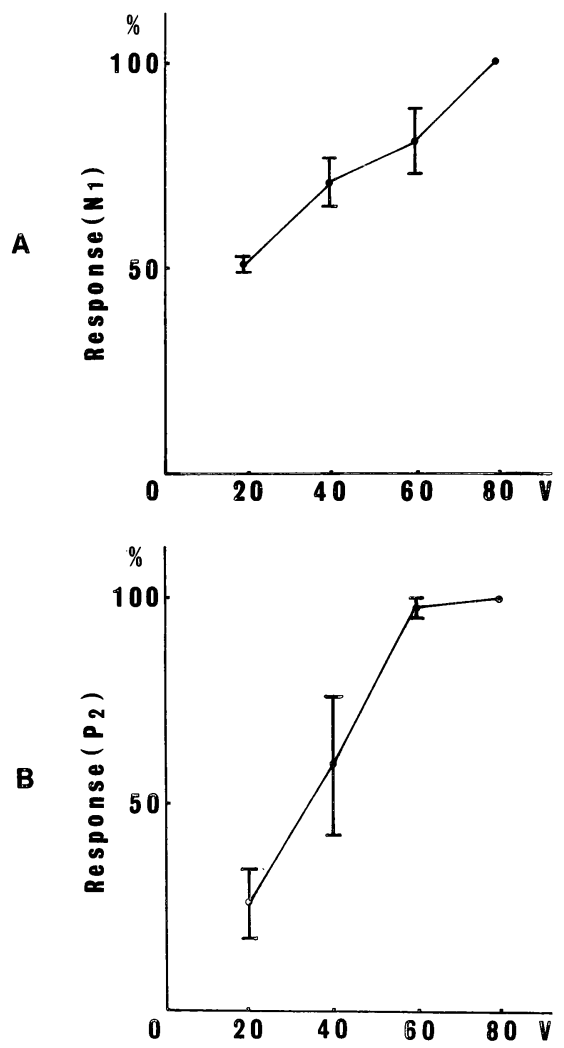

図 7 脊髄誘発電位と誘発筋電図との同時記録. 上段 の SCEP は脊髄誘発電位, 下段の EMG は肛門括約 筋の誘発筋電図をそれぞれ示す。刺激電圧 $60 \mathrm{~V}$, 加算 回数128回, 記録は 2 回ずつ行なっている。

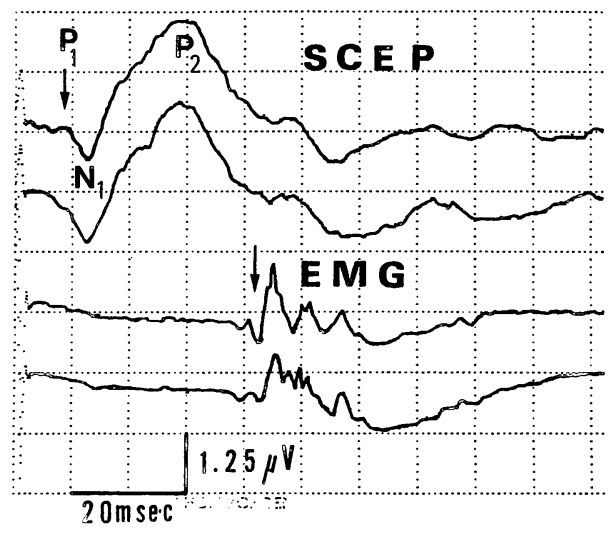

興奮が運動線維を通り肛門括約筋に至り誘発筋電図と して記録される(図 7 )。したがって, 誘発筋電図との 
同時記録を行なえば，球海綿体反射の全過程を分析で きることが明らかとなった。なお，誘発筋電図が陰茎 刺激から出現するまでの時間を，同様に末梢潜時とし て表 1 に示した。

4）神経障害部位との比較（表 2)

これまで述べてきた結果は, 頝胸䯣損傷患者 10 名か ら得たものである。したがって，仙髄およびそれ以下 の末梢神経が保存されている場合には, 分節性脊䯣誘 発電位を完全に記録することができた。この10名の患 者のうち 6 名に urodynamic studyを施行した。その 結果 6 例とも, detrusor hyperreflexia に外括約筋の非 協調運動を伴なう detrusor sphincter dyssynergia （DSD）をもつことが明らかとなった。

一方，仙䯣以下に障害があった 2 症例では, 球海綿 体反射が消失し，誘発筋電図も記録できなかった。し かし脊髄誘発電位の方には, 障害部位によって若干の 差を認めた。仙髄自体が損傷された患者では, 図 $8 \mathrm{~A}$ に 示すように誘発波形はまったく記録されなかった。な 技，この患者の urodynamic study 所見は, detrusor

図 8 仙䯣以下に障害をもつ患者の脊髄誘発電位. A は仙髄自体が損傷された場合, Bは末梢神経障害で,

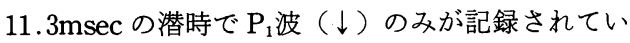
る.

A

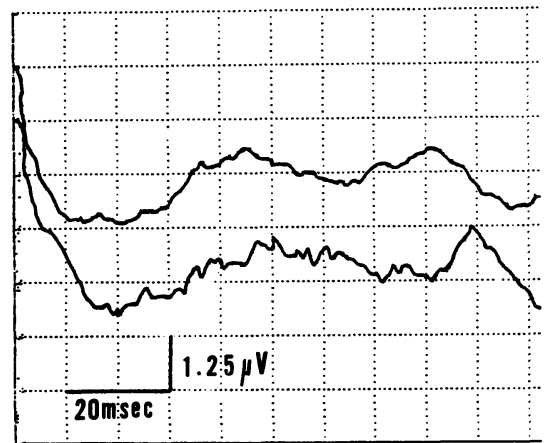

B

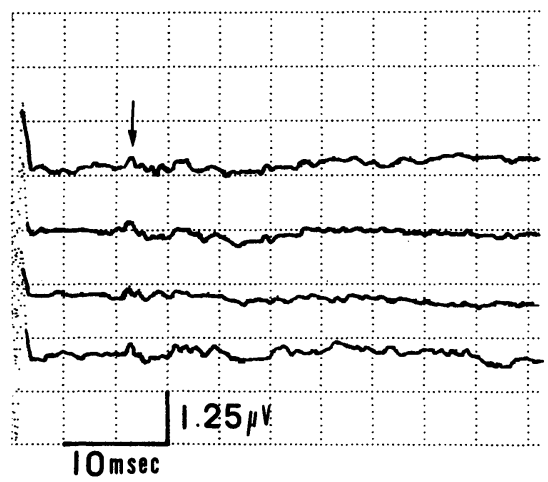

areflexia と外括約筋の活動が消失した除神経型外括 約筋（denervated external sphincter）であった。と ころが直腸癌手術に合併した末梢神経障害の症例で は, $11.3 \mathrm{msec}$ の潜時で小さな振幅をもった $\mathrm{P}_{1}$ 波だけ が出現し，後続すべき $\mathrm{N}_{1}$ 波と $\mathrm{P}_{2}$ 波は記録されなかっ た(図 8B).また， $\mathrm{P}_{1}$ 波の潜時として $11.3 \mathrm{msec}$ の值は， 先述した対照群の平均值 $9.8 \pm 0.4 \mathrm{msec}$ (表 1 ) より明 らかに延長していた。この症例の膀脱機能は同様に detrusor areflexia であったが, 外括約筋は腹圧排尿時 に弛緩しない非弛緩性外括約筋 (nonrelaxing external sphincter）を示した。

\section{考案}

これまで硬膜外導出法は, 体性知覚誘発電位 (somatosensory evoked potential) の測定方法の一つ として，扣もに四肢の末梢神経刺激時における記録に 利用されてきた。この研究では硬膜外導出法をさらに 陰茎刺激の場合にも応用し, 球海綿体反射のヒト脊髄 誘発電位を検討した。

一般に四肢の末梢神経を刺激した場合，その神経が 所属する脊髄分節にて観察される誘発電位を分節性脊 髄誘発電位（以下，分節性誘発電位と略）といい, こ の金髄分節より離れた部位から導出されるものを伝導 性脊髄誘発電位（以下，伝導性誘発電位と略）と定義 されている(11)14)15). 今回我々が検討した陰茥刺激の場 合にも，導出電極が球海綿体反射中枢のある仙髄領域 に置かれると，再現性のきわめて高い分節性誘発電位 を得ることができた。しかし，伝導性誘発電位に関し ては，電極の位置を仙髄より上位にしても記録するこ とができなかった。この理由として，伝導性誘発電位 は本来その電位が小さいため四肢の末梢神経刺激でも 導出しがたいこと息，また今回用いた陰茎刺激の強度 が伝導性誘発電位を記録するには弱すぎたことなどが 考㝋られる。

さて陰茎刺激による分節性誘発電位は特徵的な波形 を示し, 最初の陽性電位 $\left(\mathrm{P}_{1}\right.$ 波) と次に続く陰性波 $\left(\mathrm{N}_{1}\right.$ 波) および最後の緩徐な陽性波 ( $\mathrm{P}_{2}$ 波) から構成され ていた。これらの成分波は, 四肢の末梢神経刺激によっ て生ずる分節性誘発電位7)814)15) と基本的には同じで あった．球海綿体反射と同様に仙髄から分節性誘発電 位が導出される後怪骨神経刺激の場合には, 約 $10 \mathrm{msec}$ の末梢潜時で $\mathrm{P}_{1}$ 波が出現し, 中权潜時 $2 \sim 3.5 \mathrm{msec}$, 持 続 $5 \sim 8 \mathrm{msec}$ の $\mathrm{N}_{1}$ 波が記録され, 最後の $\mathrm{P}_{2}$ 波は中权潜 時が7〜 16msec，持続が20〜 $50 \mathrm{msec}$ と報告されてい る ${ }^{14) 15)}$. 一方, 本研究で検討した陰茥刺激の場合でも, 
各成分波の末梢潜時, 中枢潜時および持続時間は後怪 骨神経刺激時とほぼ同じ値を示した（表 1 ）。ただし $\mathrm{N}_{1}$ 波と $\mathrm{P}_{2}$ 波の中权潜時がやや延長する傾向を示した ことについては，検討を加えた症例数も少ないため, これが球海綿体反射に特有な現象かどらかは結論でき ない。

さらに今回の検討から, $\mathrm{P}_{1}$ 波, $\mathrm{N}_{1}$ 波および $\mathrm{P}_{2}$ 波は刺 激強度に対する反応がそれぞれ異なっていることが明 らかとなった。すなわち， $\mathrm{P}_{1}$ 波は閾值がもっとも低く 弱刺激でも容易に出現し， $\mathrm{N}_{1}$ 波は刺激強度にほぼ比例 して増加し, 最後の $\mathrm{P}_{2}$ 波は刺激強度 $60 \mathrm{~V}$ 位で反応が飽 和する性質を示した。これらの結果は, 各成分波の起 源がおたがいに異なることを示唆している.

実際に四肢の末梢神経刺激によって得られる分節性 誘発電位の起源については, 現在のところ次のよらな 見解が得られている， $P_{1}$ 波はもっとも誘発されやすい スパイク電位で, 後根から脊髄内に流入する神経活動 電位と考号られている8)16177). $\mathrm{N}_{1}$ 波は動物実験で記録 されるシナプス後性の春䯣背面陰性電位と同じ起源を もち，二重刺激の不応期やバルビタール，八ロセン， モルフィンによる影響の特異性から, 脊䯣内二次 ニューロンおよび介在ニューロンの電位を表わ

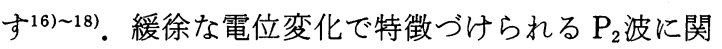
しては, 実験動物の脀䯣背面陽性電位と同様にバルビ タールで増大し，モルフィンやケタミンで減少するこ とから, 一次求心性線維末端に生ずる脱分極 (primary afferent depolarization=以下 PAD と略）を反映する と言われている(1719)20). この PAD とは, 末梢から伝播 してきた興奮がシナプス前性に抑制された結果生ずる 求心性線維末端の脱分極であり, presynaptic inhibition $^{21)}$ と呼ばれる脊髄内反射抑制機構の一種で ある.さらにPADをもたらす神経伝達物質は, GABA (gamma aminobutyric acid) であることが知られて いる2223).したがって， $\mathrm{P}_{1}, \mathrm{~N}_{1}$ および $\mathrm{P}_{2}$ 波を記録でき る硬膜外導出法は, 球海線体反射の場合でも体表面導 出法 ${ }^{24)}$ 上りはるかに多くの脊髄内情報を提供できるこ とは明らかである。

次に神経障害部位や urodynamic study との関係を みると, 䅡胸髄損傷患者 10 例については分節性誘発電 位を完全な形で記録することができた。これらの患者 では仙髄から末梢神経に至る反射弓が保存されて招 り, 球海綿体反射の伝導時間も正常と变りないと報告 されていることから ${ }^{25) 26)}$, 仙髄から誘発電位が記録で きるのは当然のことと考兄られる。しかし厳密に言う
と, この 10 例の患者から得られた脊髄誘発電位が，正 常人と完全に同一かについては若干の問題がある.そ の理由は, 硬膜外導出法で得られる成分波のらち $\mathrm{N}_{1}$ 波と $\mathrm{P}_{2}$ 波は, 大脳をはじめとする上位中枢から微妙な 影響を受けることが報告されているからである22127). 実際には上位中枢からの影響はそれ的ど大さとは揖 むわれないが，この問題については正常人をコント ロールとして利用できない点も含め，今後検討を加え る必要がある。

またこれら10例のらち urodynamic studyを施行 した 6 例は，核上型春䯣損傷に特有な DSD を伴なう detrusor hyperreflexia を示した. この所見と脊䯣誘発 電位との関係を直接論ずることは, 現段階で症例数も 少ないため無理である。しかし, 最近 baclofen という 薬剤が DSDを改善したとする報告がなされてお $\eta^{28)}, \mathrm{P}_{2}$ 波と DSD との関係を示唆するものとして興 味深い，一般に baclofen はGABA と同様に脊髄内一 次求心線維末端に作用し, DSDのような病的反射を抑 制すると言われている。したがって，一次求心線維の 電気活動 $(\mathrm{PAD})$ を映する $\mathrm{P}_{2}$ 波は, DSD の程度や治 療効果を見る指標となるばかりでなく，その発生機序 を解明する上でも役立つと考兄られるからである.

一方，仙髄やそれ以下の末梢神経に障害があると， 分節性誘発電位はほとんぞ記録されなくなる，検討を 加光た 2 例のうち仙髄自体に損傷のある患者では, 誘 発波形の再現性を認めず誘発不能と判定された。とこ ろが，直腸癌術後に合併した末梢神経障害例において は，遅れた潜時で $\mathrm{P}_{1}$ 波だけが記録され $\mathrm{N}_{1}$ 波や $\mathrm{P}_{2}$ 波は 出現しなかった。この現象の説明として，ごく一部に 残存する末梢神経が陰茎刺激を不完全ながらも後根近 傍までは伝播するが，その電気的興奮が伝播する過程 ですでに減弱してしまい, 次の $\mathrm{N}_{1}$ 波や $\mathrm{P}_{2}$ 波を誘発す るだけの起電力を失なっていたものと推定される。

これら 2 例の urodynamic studyで, 排尿筋の方は いずれも detrusor arflexia であったが，外括約筋はそ れぞれ異なった動態を示した．前述したよらに分節性 誘発電位がまったく記録されなかった症例は外括約筋 も除神経型で非活動性であったのに対し， $\mathrm{P}_{1}$ 波だけが 誘発された方は外括約筋の活動が残っている非弛緩型 を示した，したがって，今後さらに多くの症例につい て検討を重ねると, 同じ仙髄以下の障害でも, 障害の 程度や部位, urodynamic study の所見に応じて特徵的 な沗髄誘発電位を記録できることが示唆された。

以上述べてきたよらに，硬膜外導出法による春髄誘 
発電位の記録は，脊䯣内ニューロンに関する豊富な情 報を提供するので，神経因性膀胼尿道障害の新しい診 断法として，またDSD などの病態解明の手段として， 今後に期待される有力な方法であると扔もわれる。

\section{結語}

1）球海綿体反射時における七ト资髄誘発電位は, 硬 膜外導出法によって確実に記録できる。

2）陰茎刺激の場合，導出電極を仙髄の高さに置く と, 再現性のある分節性脊䯣誘発電位を得ることがで きる。

3）球海綿体反射による分節性誘発電位は, 四肢の末 梢神経刺激時に得られるものと同一で, $\mathrm{P}_{1}$ 波, $\mathrm{N}_{1}$ 波打 よび $\mathrm{P}_{2}$ 波で構成される特徴的波形を示した。

4) これらの成分波 $\left(\mathrm{P}_{1}\right.$ 波， $\mathrm{N}_{1}$ 波， $\mathrm{P}_{2}$ 波) は，電気刺 激強度に対する反応が拈たがいに異なっていた。

5）肛門括約筋の誘発筋電図と同時記録すると, 球海 綿体反射弓の全過程を検討することができる。

6）頝胸髄損傷患者10名からは，分節性誘発電位を完 全な形で記録できた。このうち urodynamic studyを 施行した 6 名は, DSDを伴な 5 detrusor hyperreflexia を示した。

7）仙髄以下に障害のある 2 名は urodynamic study 上いずれも detrusor areflexiaを示した。このうち仙 䯣損傷をもった患者では，脊髄誘発電位を記録できな かった。もら 1 例の直腸癌手術に合併した末梢神経障 害では，潜時の延長した $\mathrm{P}_{1}$ 波だけが記録され，後続す べき $\mathrm{N}_{1}$ 波や $\mathrm{P}_{2}$ 波は出現しなかった。

本研究の一部は, 第33回日本泌尿器科学会総会(東京) で 発表した。 また, 測定技術の援助をいただいた熱海総合病院 生理検査室の斉藤氏に深く感謝いたします。

\section{文献}

1) Badr, G.G., Fall, M., Carlsson, C., Lindstrom, L., Friberg, S. and Ohlsson, B.: Cortical evoked potentials obtained after stimulation of the lower urinary tract. J. Urol., 131, 306-309, 1984.

2) Bradley, W.E., Timm, G.W., Rokswold, G.L. and Scott, F.B.: Detrusor and urethral electromyelography. J. Urol., 114, 891-894, 1975.

3) Yalla, S.V., Benedetto, M., Blunt, K.J., Sethi, J. M. and Fam, B.A. : Urethral striated sphincter responses to electrobulbocavernosus stimulation. J. Urol., 119, 406-409, 1978.

4) Nordling, J., Andersen, J.T., Walter, S., Meyhoff, H.H., Hald, T. and Gammelgaard, P.
A.: Evoked response of the bulbocavernosus reflex. Eur. Urol., 5, 36-38, 1979.

5) Krane, R.J. and Siroky, M.B.: Studies on sacral-evoked potentials. J. Urol., 124, 872-876, 1980.

6) Kaneko, S., Park, Y.C., Yachiku, S. and Kurita, T.: Evoked central somatosensory potentials after penile stimulation in man. Urology, 21 , 58-59, 1983.

7) Shimoji, K., Kano, T. and Higashi, H.: Epidural recording of spinal electrogram in man. Electroencephalog. Clin. Neurophysiol., 30, 236-239, 1971.

8) Shimoji, K., Kano, T., Higashi, H., Morioka, T. and Henschel, E.O.: Evoked spinal electrograms recorded from epidural space in man. J. Appl. Physiol., 33, 468-471, 1972.

9）清水裕幸, 丸山洋一, 佐藤祐次: 春䯣誘発電位から 久た慢性脊㖪疾患の春䯣機能。臨床脳波, 20, 227-235, 1978.

10）吉田 護, 松角康彦, 吳屋朝和, 下地恒毅：春髄疾 患に抢ける誘発春髄波。臨床生理，13，745-752， 1973.

11）黑川高秀：誘発脊䯣電位（II）。臨床脳波，17, 123-131, 1975.

12）玉置哲也, 山根友二郎, 小林英夫, 井上駿一：脊䯣 モニタリング法一誘発沗髄電位に対する anoxia の影響について一.脳波と筋電図, 5, 37-39, 1977.

13）坪川孝志：脊䯣損傷に抢ける春䯣誘発電位の臨床 的意義. 臨床脳波，20，236-243，1981。

14）丸山洋一，下地恒毅：春髄誘発電位一その起源に ついて一。神経進歩, 23, 397-408, 1979.

15）下地恒毅：硬膜外導出法によるヒ卜脊䯣誘発電位 の臨床応用関する研究. 日医会誌, 91, 113-120, 1984.

16) Shimoji, K., Matsui, M., Ito, Y., Masuko, K., Maruyama, M., Iwane, T. and Aida, S. : Interactions of human cord dorsum potential. J. Appl. Physiol., 40, 79-84, 1976.

17) Shimoji, K., Ito, Y., Ohama, K., Sawa, T. and Ikezono, E.: Presynaptic inhibition in man during anesthesia and sleep. Anesthesiology, 43, 388-391, 1975.

18) Shimoji, K., Kano, T., Nakashima, H. and Shimizu, H.: The effects of thiamylal sodium on electrical activities of the central and peripheral nervous system in man. Anesthesiology, 40, 234-240, 1974.

19) Maruyama, Y., Shimoji, K., Shimizu, H., Kuribayashi, H. and Fujioka, H.: Human spinal cord potentials evoked by different sources of stimulation and conduction velocities along the 
cord. J. Neurophysiol., 48, 1098--1107, 1982.

20) Eccles, J.C., Kostyuk, P.G. and Schmidt, R.F.: Central pathways responsible for depolarization of primay afferent fibers. J. Physiol., 161, 237-257, 1962.

21) Eccles, J.C., Schmidt, R.F. and Willis, W.D. : Presynaptic inhibition of the spinal monosynaptic reflex pathway. J. Physiol., 161, 282-297, 1962.

22) Barber, R.P., Vaughn, J.E., Saito, K., McLaughlin, B.J. and Roberts, E.: GABA-ergic terminals are presynaptic to primary afferent terminals in the substantia gelatinosa of the rat spinal cord. Brain Research, 141, 35-55, 1978.

23) Levy, R.A.: The role of GABA in primary afferent depolarization. Progr. Neurobiol., 9, 211-267, 1977.

24) Cracco, R.Q. : Spinal evoked response. Periph- eral nerve stimulation in man. Electroencephalogr. Clin. Neurophysiol., 35, 379-386, 1973.

25）古屋望児, 横山英二, 熊本悦明, 塚本泰司：誘発筋 電困に上る球海綿体広射の伝導時間測定. 日泌尿 会誌, 74, 15-24, 1983.

26）朴 英哲, 江左篤宣, 杉山高秀, 金子茂男, 栗田 孝：排尿機構にかんする検討. 第12報. 誘発筋電図 法による球海綿体反射の検討. 日泌尿会誌，76, 1184-1153, 1985.

27) Ertekin, C.: Evoked electrospinogram in spinal cord and peripheral nerve disorders. Acta Neurol. Scandinav., 57, 329-344, 1978.

28) Leyson, J.F.J., Martin, B.F. and Sporer, A.: Baclofen in the treatment of detrusor-sphincter dyssynergia in spinal cord injury patients. J. Urol., 126, 82-84, 1980.

（1986年 4 月 14 日受付） 